\title{
TAPETUM - A MISUNDERSTOOD TOPIC
}

\author{
P K Sharma ${ }^{1}$, Sonia Jaiswal ${ }^{1}$
}

1. Department of Anatomy, Era's Lucknow Medical College, Lucknow, India

\begin{abstract}
Quite frequently students are asked to explain tapetum. We found that various books of anatomy have different explanations. Students are confused as to which book must be followed for its explanation. We are therefore writing an inference drawn by consulting books and also by observing the human brain in cadavers.
\end{abstract}

Keywords: Tapetum, Corpus Callosum, Lateral Ventricle, Posterior Horn, Inferior Horn

\section{DEFINITION}

The tapetum was described by Johann Christian Rell (1759-1813). It is formed primarily by decussating fibers in the splenium of the corpus callosum that arch over the atrium of the lateral ventricle and course inferiorly in the lateral wall of the posterior, and somewhat into the temporal horns of the lateral ventricle.[1]

\section{WHAT DO THE BOOKS SAY ABOUT TAPETUM}

1. "Those fibres of the trunk and splenium of corpus callosum which together form the roof and lateral of the posterior horn and lateral wall of the inferior horn of the lateral ventricle constitute the tapetum." [2]

2. "A large number of fibres from the trunk of corpus callosumrun transversely to intersect with the fibres of the corona radiata. Some fibres of the trunk and adjacent splenium which do not intersect with corona radiate are known as tapetum. The tapetum is closely related to the inferior horn and posterior horn of the lateral ventricle." [3]

3. "The tapetum is athin lamina of white fibres ( $2 \mathrm{~cm}$ thick) which forms the roof and lateral wall of the posterior horn and lateral wall of the inferior horn of the lateral ventricle. The tapetum is formed by those fibres of the trunk and splenium of corpus callosum which are not intersected by the fibres of corona radiata. In the coronal section, the tapetum looks whiter than the surrounding white matter because section passes parallel to the fibres of the tapetum." [4]

4. "Some of the fibres of the corpus callosum form the roof and lateral wall of the posterior

Address for Correspondence:

Prof PK Sharma, HOD Anatomy, Era's Lucknow Medical College, Lucknow, (U.P.), India - 226003

Email - drpksharma_50@yahoo.com

Date of Receiving: 27 August 2020

Date of Acceptance: 11 September 2020

0970-1842/Copyright @ JAS 2020 
horn of the lateral ventricle and the lateral wall of the inferior horn of the lateral ventricle; these fibresare referred to as tapetum." [5]

5. "The roof and lateral wall is formed by the tapetum of the corpus callosum, with the optic radiation lying against the tapetum in the lateral wall." [6]

\section{CONCLUSION}

Tapetum literally means a reflective layer. In the human brain tapetum consists of those fibres of splenium of corpus callosum which form the roof, lateral and inferior wall of the posterior horn and lateral wall of the inferior horn of the lateral ventricle. They look whiter than the white matter because they are cut parallel to the fibres it contains [7].

In many animals, it is a reflective layer of the choroid of the eye causing them to shine in the dark.

\section{REFERENCES}

1. Levent Sarikcioglu, Umut Ozsoy \& Guray Unver (2007) Tapetum Corporis Callosi: Carpet of the Brain, Journal of the History of the Neurosciences, 16:4, 434-436, DOI: 10.1080/09647040600719013

2. Standring, S., Borley, N. R., \& Gray, H. Gray's anatomy: the anatomical basis of clinical practice. 40th ed., anniversary ed. Edinburgh: Churchill Livingstone/Elsevier; 2008

3. Pritha S Bhuiyan, Lakshmi Rajgopal, K Shyam Kishore. Inderbir Singh's Textbook of Human Neuroanatomy. $10^{\text {th }}$ ed. Jaypee Brothers Medical Publishers (P) Ltd; 2018
4. Vishram Singh. Textbook of Clinical Neuroanatomy. $2^{\text {nd }}$ ed. Elsevier; 2010

5. Richard S Snell. Clinical Neuroanatomy. $7^{\text {th }}$ ed. Wolter Kluwer Health/Lippincott Williams \&Wilkins; 2010.

6. Chummy S. Sinnatamby. Last's Anatomy. $12^{\text {th }}$ ed. Elsevier; 2011

7. G.J Romanes. Cunningham's Manual of Practical Anatomy Vol 3. $15^{\text {th }}$ ed. Oxford University Press; 1986. 